\title{
Using modern ferruginous habitats to interpret Precambrian banded iron formation deposition
}

\author{
Elif Koeksoy', Maximilian Halama', Kurt O. Konhauser ${ }^{2}$ and Andreas Kappler' \\ ${ }^{1}$ Department of Geomicrobiology, Center for Applied Geosciences, University of Tuebingen, Tuebingen, Sigwartstrasse 10, \\ D-72076 Tuebingen, Germany e-mail: andreas.kappler@uni-tuebingen.de \\ ${ }^{2}$ Department of Earth and Atmospheric Sciences, University of Alberta, Edmonton, Alberta T6G 2E3, Canada
}

\begin{abstract}
Early Earth processes are typically identified through the study of mineralogical, elemental and isotopic features in the rock record, including Precambrian banded iron formations (BIF). However, postdepositional processes often obscure the primary geochemical signals, making the use of BIF as proxies for paleo-seawater and the paleo-biosphere potentially imprecise. Thus, alternative approaches are required to complement the information gained from the rock record in order to fully understand the distinctive biogeochemical processes on ancient Earth. Simulating these conditions in the laboratory is one approach, but this approach can never fully replicate the complexity of a natural environment. Therefore, finding modern environments with a unique set of geochemical and microbiological characteristics to use as analogues for BIF depositional environments can provide invaluable information. In this review, we provide an overview of the chemical, physical and biological parameters of modern, ferruginous lakes that have been used as analogue BIF environments.
\end{abstract}

Received 10 June 2015, accepted 4 August 2015, first published online 30 September 2015

Key words: ancient oceans, banded iron formations, geobiology, modern model habitats.

\section{Precambrian seawater composition, biogeochemical processes and banded iron formations (BIF) deposition}

The composition of Archean seawater has largely been interpreted through the study of BIF, Fe- and Si-rich chemical sedimentary rocks that precipitated directly out of seawater since at least $3.8 \mathrm{Ga}$ years ago (Mloszewska et al. 2012). BIF are typically composed of quartz (in the form of chert), magnetite, hematite, Fe-rich silicate minerals (stilpnomelane, minnesotaite, greenalite and riebeckite), carbonate minerals (siderite, ankerite, calcite and dolomite) and minor amounts of sulphide minerals (pyrite and pyrrhotite). The presence of both, ferric and ferrous minerals give BIF an average oxidation state of $\mathrm{Fe}^{2.4+}$ (Klein \& Beukes 1992) which means that $60 \%$ of $\mathrm{Fe}$ in BIF is made up by $\mathrm{Fe}(\mathrm{II})$. The deposition of such a high quantity of iron as present in BIF required transport of huge amounts of dissolved $\mathrm{Fe}(\mathrm{II})$, most probably introduced by hydrothermal venting to the seawater (Holland 1973), to the deposition sites in Precambrian shelf regions where it was either microbially or abiotically oxidized (Posth et al. 2013b). A mostly anoxic water column was necessary to maintain $\mathrm{Fe}(\mathrm{II})$ remained in solution. Under such conditions, oxidized anions as sulphate $\left(\mathrm{SO}_{4}^{2-}\right)$ were present in much lower concentrations (Table 1) than nowadays resulting in a different microbial community as well as a different elemental composition compared with modern oceans (Habicht et al. 2002).
The iron minerals in BIF are of particular interest in studies focusing on modelling the Precambrian seawater environment (Fig. 1), and have been used extensively as proxies for the abundance of trace metals in the ancient ocean (e.g., Bjerrum \& Canfield 2002; Konhauser et al. 2009; Mloszewska et al. 2012; Partin et al. 2013; Robbins et al. 2013). While BIF mineralogy reflects significant post-depositional alteration under diagenetic and metamorphic conditions, the layers of magnetite and hematite are interpreted to have formed from an initial Fe(III) (oxyhydr)oxide phase, e.g. ferrihydrite $\left(\mathrm{Fe}(\mathrm{OH})_{3}\right)$ (Klein 2005; Posth et al. 2008). It is thought to have precipitated in the photic zone of the water column when dissolved ferrous iron $\left(\mathrm{Fe}^{2+}\right)$ was oxidized and hydrolysed to poorly soluble ferric iron minerals. The Fe(III) (oxyhydr)oxide particles then sank through the water column and deposited on the seafloor where they eventually transformed to: (1) magnetite or Fe(II)-containing carbonates by abiotic and microbial Fe(III) reduction; (2) the more stable $\mathrm{Fe}(\mathrm{III})$ oxide hematite in case the $\mathrm{C}_{\text {org }}$ content was low in sediments leading to dehydration of the Fe(III) (oxyhydr)oxides under the elevated pressure and/or temperature; or (3) to iron silicates, possibly in the form of a precursor mineral such as greenalite, when silica-sorbed Fe(III) (oxyhydr)oxides reacted with other cationic species in the sediment pore waters (e.g., Morris 1993; Konhauser et al. 2005; Johnson et al. 2008; Posth et al. 2013b; Posth et al. 2014; Rasmussen et al. 2015; Sun et al. 2015). Indeed, silica concentrations are assumed to have been high in the Precambrian oceans, reaching concentrations of at least $0.67 \mathrm{mM}$ (supersaturation with respect to crystobalite) and 
Table 1. Comparison of the chemical and physical composition of the Archean, Proterozoic and modern ocean including respective estimates on the atmospheric oxygen content given in \% present atmospheric level ( $P A L)$

\begin{tabular}{llll}
\hline & Archean & Proterozoic & \multicolumn{1}{c}{ Modern } \\
\hline $\mathrm{O}_{2}(\% \mathrm{PAL})$ & $<0.001^{2}$ & $10-20^{2}$ & 100 \\
$\mathrm{Fe}(\mathrm{II})(\mu \mathrm{M})$ & $40-120^{1}$ & $0.1-0.5^{2}$ & $<0.001^{2}$ \\
$\mathrm{PO}_{4}^{3-}(\mu \mathrm{M})$ & $0.04-0.13^{8}$ & $0.04-0.13$ & $0.17-1.44^{9}$ \\
$\mathrm{SO}_{4}^{2-}(\mu \mathrm{M})$ & $0.06-0.08^{4}$ & $500-3000^{6}$ & $28000^{5}$ \\
$\mathrm{~S}^{2-}(\mu \mathrm{M})$ & n.a. & n.a. & $<0.001^{2}$ \\
$\mathrm{SiO}_{2(\mathrm{aq})}(\mu \mathrm{M})$ & $670-2200^{7}$ & $670-2200^{7}$ & $10-180^{7}$ \\
$\mathrm{pH}$ & $>6.5^{2}$ & $>6.5^{2}$ & $8.1^{2}$ \\
$\mathrm{~T}\left({ }^{\circ} \mathrm{C}\right)$ & $\sim 40-70^{3}$ & n.a. & $-2-36$ \\
\hline
\end{tabular}

n.a., not available.

${ }^{1}$ Canfield (2005)

${ }^{2}$ Saito et al. (2003)

${ }^{2}$ Holland (2006)

${ }^{3}$ Grotzinger \& Kasting (1993)

${ }^{4}$ Crowe et al. (2014)

${ }^{5}$ Jorgensen (1982)

${ }^{6}$ Canfield (1998)

${ }^{7}$ DeMaster et al. (1995)

${ }^{8}$ Jones et al. (2015)

${ }^{9}$ Conkright et al. (2000)

possibly as high as $2.2 \mathrm{mM}$ (Siever 1992; Maliva et al. 2005; Konhauser et al. 2007) (Table 1).

Trace element sequestration by authigenic Fe(III) (oxyhydr) oxides, such as ferrihydrite, results from a continuum of adsorption and co-precipitation reactions. As a consequence, lumped-process distribution coefficient models can be used to relate the concentration of an element in the $\mathrm{Fe}$ (III) (oxyhydr) oxide to the dissolved concentration present at the time of precipitation. This predictive aspect of metal sorption reactions has been exploited to better understand the BIF record with respect to ancient seawater composition and nutrient limitations on Precambrian primary productivity. For instance, it has been proposed that low $\mathrm{P}$ concentrations in Archean and Paleoproterozoic BIF indicate limited marine phosphorous availability at that time (10-25\% of present-day concentrations; Konhauser et al. 2007) (Table 1), which would have reduced the levels of photosynthesis and carbon burial, thereby inhibiting long-term oxygen production on the early Earth (Bjerrum \& Canfield 2002). Similarly, it has been shown that the nickel content in BIF has changed dramatically over time, and that a drop in $\mathrm{Ni}$ availability in the oceans around 2.7 billion years ago would have had profound consequences for microorganisms that depended on it, that being methaneproducing bacteria called methanogens (Konhauser et al. 2009). These bacteria have a unique Ni requirement for their methane-producing enzymes $(<100 \mathrm{~nm}$; Schönheit et al. 1979), and importantly, these bacteria have been implicated in controlling the oxygen levels on the ancient Earth as the methane they produced was reactive with oxygen and kept the atmospheric oxygen levels low. It is possible that a $\mathrm{Ni}$ famine eventually led to a cascade of events that began with reduced methane production, the expansion of cyanobacteria into shallow-water settings previously occupied by methanogens, and ultimately increased oxygenic photosynthesis that tipped the atmospheric balance in favour of oxygen, the so-called Great Oxidation Event (GOE) at 2.45 Gyr.

It is widely accepted that photosynthetic bacteria played a crucial role in $\mathrm{Fe}(\mathrm{II})$ oxidation and the precipitation of BIF primary minerals throughout the Archean and Paleoproterozoic (see Posth et al. 2013b for review). Some of the earliest models of BIF deposition suggested that the abiotic oxidation of dissolved $\mathrm{Fe}$ (II) took place in the presence of free oxygen derived from oxygenic photosynthesis via the evolution of cyanobacteria (Cloud 1973). However, on a dominantly anoxic Earth before 3.0 Ga (Crowe et al. 2013; Planavsky et al. 2014), the role of oxygen in terms of BIF deposition, if it existed, would have been limited. In this regard, anoxygenic photosynthetic bacteria (e.g., green and purple bacteria), which use Fe(II) as an electron donor for carbon assimilation rather than water and produce Fe(III) instead of dioxygen (e.g., Widdel et al. 1993), most probably colonized the anoxic waters of the Archean ocean. Laboratory experiments demonstrated that this form of metabolism could generate sufficient quantities of $\mathrm{Fe}$ (III) to account for all the oxidized iron in BIF even at rapid accumulation rates (Kappler et al. 2005; Konhauser et al. 2002). Fe(II) oxidation by anoxygenic phototrophs can be sustained in relatively deep waters (as much as $100 \mathrm{~m}$ of water depth) (Kappler et al. 2005), and their growth is not hindered by high concentrations of dissolved silica (Posth et al. 2008; Wu et al. 2014). Therefore, these organisms could easily have oxidized all of the upwelling Fe(II) before it made contact with the overlying oxygenated waters (if these existed) in the early Archean oceans (Czaja et al. 2013; Pecoits et al. 2015). As the redox state of the ocean most probably changed after the GOE in form of a slight oxygenation of the surface waters and anoxic bottom layers, the abundances of different types of bacteria must have changed crucially. For instance, microaerophilic $\mathrm{Fe}$ (II)-oxidizing bacteria likely thrived at the oxic-anoxic interface and contributed to the formation of $\mathrm{Fe}$ (III) (oxyhydr) oxides (Holm 1989) in addition to anoxygenic photoferrotrophs that probably further colonized the anoxic photic zone. Because of the role microbes played in $\mathrm{Fe}$ (II) oxidation, the focus of a number of recent experimental studies on BIF deposition has been on how organic carbon may have: (1) influenced trace metal sorption to the precursor ferrihydrite particles, and (2) affected the remobilization of trace metals during diagenesis and metamorphism when the heterotrophic respiration of the biomass would have been coupled to some form of terminal electron accepting process, such as $\mathrm{Fe}(\mathrm{III})$ reduction. In the case of the former, Eickhoff et al. (2014) recently examined the partitioning of $\mathrm{Ni}$ to both abiogenic and biogenic ferrihydrite. They demonstrated that when normalized to the specific surface area, biogenic ferrihydrite sorbed less $\mathrm{Ni}$, apparently due to microbially derived organics or whole cells binding to the mineral surface and thereby competing with $\mathrm{Ni}$ for sorption sites. Given the potential for co-precipitating organic matter to depress partitioning of $\mathrm{Ni}$, the Eickhoff study suggested that previous estimates for $\mathrm{Ni}$ concentrations in Archean seawater may be too low, and that the decline of $\mathrm{Ni}$ in Precambrian ocean may have occurred closer to the GOE, at $2.45 \mathrm{Ga}$. In 

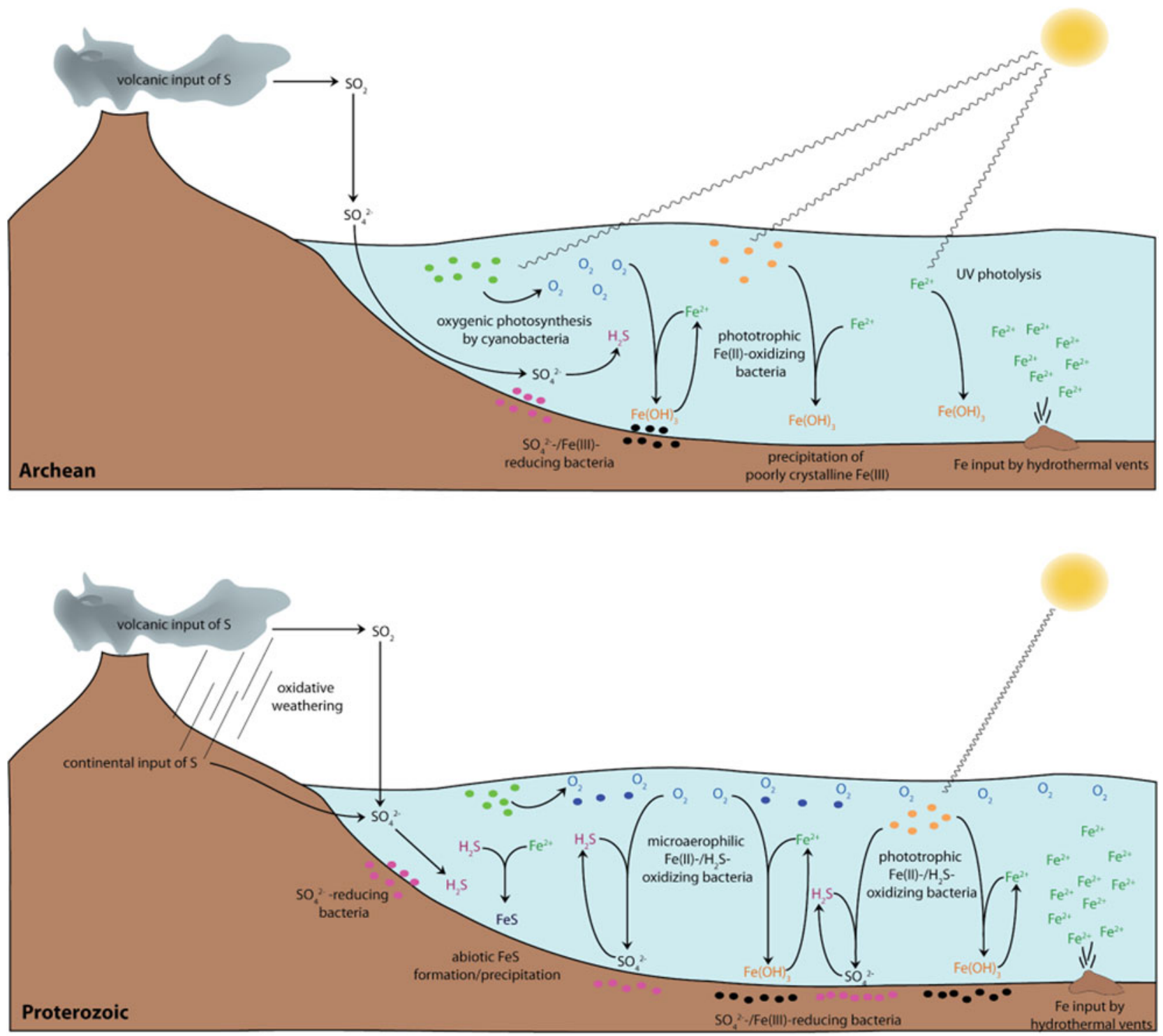

Fig. 1. Overview of the Fe-S biogeochemistry in the Archean and Proterozoic ocean. Archean: Fe(II) was introduced into the ocean hydrothermally and remained in its reduced state as oceans were dominantly anoxic. The occurrence of Fe(III) in the BIF record from that time can be explained by three different processes: (1) UV photolysis of Fe(II), (2) microbial oxidation of Fe(II) by photoautotrophic bacteria and (3) abiotic oxidation of $\mathrm{Fe}$ (II) by oxygen that started getting produced in minor amounts by cyanobacteria in the late Archean. Fe(III) was reduced to Fe(II) coupled to the oxidation of $\mathrm{H}_{2}$ /organic $\mathrm{C}$ by Fe(III)-reducing bacteria. Sulphate mainly was introduced into the ocean by volcanic input in form of $\mathrm{SO}_{2}$ that further got oxidized to $\mathrm{SO}_{4}^{2-}$ prior to its transfer to the ocean water. Sulphate-reducing bacteria already produced small amounts of $\mathrm{H}_{2} \mathrm{~S}$ by oxidizing $\mathrm{H}_{2}$ and/or organic carbon. Proterozoic: The ocean surface was slightly oxic after the $\mathrm{GOE}$ as $\mathrm{O}_{2}$ also started accumulating in the atmosphere. Increased oxidative weathering increased sulphate concentrations in the ocean by continental input in addition to volcanic input. Sulphate-reducing bacteria produced high amounts of sulphide which started accumulating under the reducing conditions of the deep ocean. Microaerophilic bacteria started flourishing under microoxic conditions and oxidized Fe(II) and $\mathrm{H}_{2} \mathrm{~S}$ to Fe(III) and sulphate, respectively. Fe(II) and $\mathrm{H}_{2} \mathrm{~S}$ reacted and precipitated in form of FeS minerals which is preserved in the rock record. Phototrophic sulphide-oxidizing bacteria started being highly active in the photic zone of the water column and oxidized accumulating $\mathrm{H}_{2} \mathrm{~S}$ to sulphate.

the case of the latter, coupling the reduction of Fe(III) minerals to the oxidation of organic matter not only explains the low content of organic carbon in BIF $(<0.5 \%$; Gole \& Klein 1981), but it also explains the prevalence of light carbon isotope compositions in associated carbonate minerals (e.g., Walker 1984), and light iron isotope compositions of magnetite and siderite (e.g., Johnson et al. 2008; Craddock \& Dauphas
2011). In this regard, Posth et al. (2013a) and Köhler et al. (2013) both demonstrated that by incubating ferrihydrite at $1.2 \mathrm{kbar}$ and $170^{\circ} \mathrm{C}$ (conditions that mimic some BIF burial conditions) for only 14 days, the mineralogical transition from ferrihydrite to hematite is already accomplished. The addition of organic carbon to these diagenetic experiments led to the formation of reduced, i.e. Fe(II)-containing minerals 


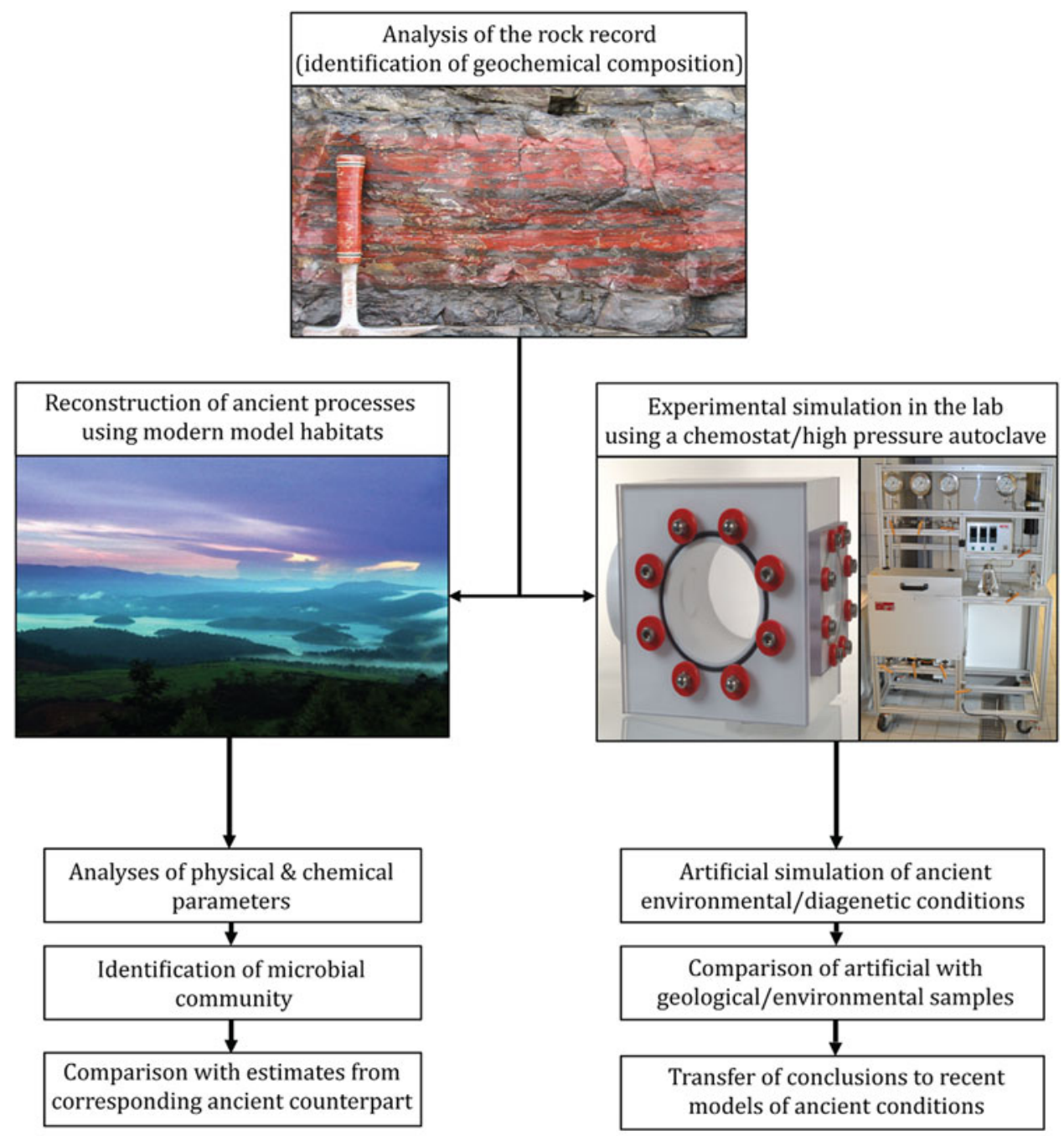

Fig. 2. Different approaches to evaluate the mineralogy, geochemistry and geomicrobiology of Archean and Proterozoic environments.

in the post-diagenetic capsules, mainly a mixture of hematite, magnetite and siderite, a composition broadly consistent with the modern day mineralogy of BIF. Robbins et al. (2015) took this one step further, demonstrating that during these diagenetic mineral transformations, $\mathrm{Ni}$ and $\mathrm{Zn}$ remained largely immobile.

\section{Modern environments as ancient analogues}

A complete and accurate picture of all the important biogeochemical processes occurring in the Archean is impossible, if based solely on geological and geochemical observations, because the rock record is incomplete and has been altered by post-depositional processes (Sadler 1981). Laboratory experiments that simulate BIF diagenesis or performing mineral precipitation experiments under Archean ocean compositions has also yielded valuable information (Kappler et al. 2005; Konhauser et al. 2005; Posth et al. 2008, 2013a; Köhler et al. 2013), but the conditions for these experiments are based on estimations for seawater conditions at that time, and the data derived are based on artificial systems which will never be able to represent the complexity of natural systems. There is thus a high probability of overlooking important parameters that are either impossible to integrate into the experimental setup or are basically ignored. Furthermore, proxies derived from geochemical modelling or from the rock record, on which the experimental designs are based on, might be inaccurate or imprecise (for example, estimates on the $\mathrm{pH}$ and temperature of the ancient ocean).

A way forward is through the study of modern environments that have geochemical conditions that might mimic Archean oceans. These analogues would include aqueous environments with the simultaneous presence of $\mathrm{Si}$ and $\mathrm{Fe}(\mathrm{II})$ at high concentrations, and a corresponding deficiency in sulphate in case of the Archean ocean. Correlation of observations from such model habitats to results from simulative laboratory experiments can improve our current understanding of biogeochemical processes occurring in the Archean oceans (Fig. 2). In this review, we present five such model habitats which we evaluate for their suitability as modern analogues. All of them are 


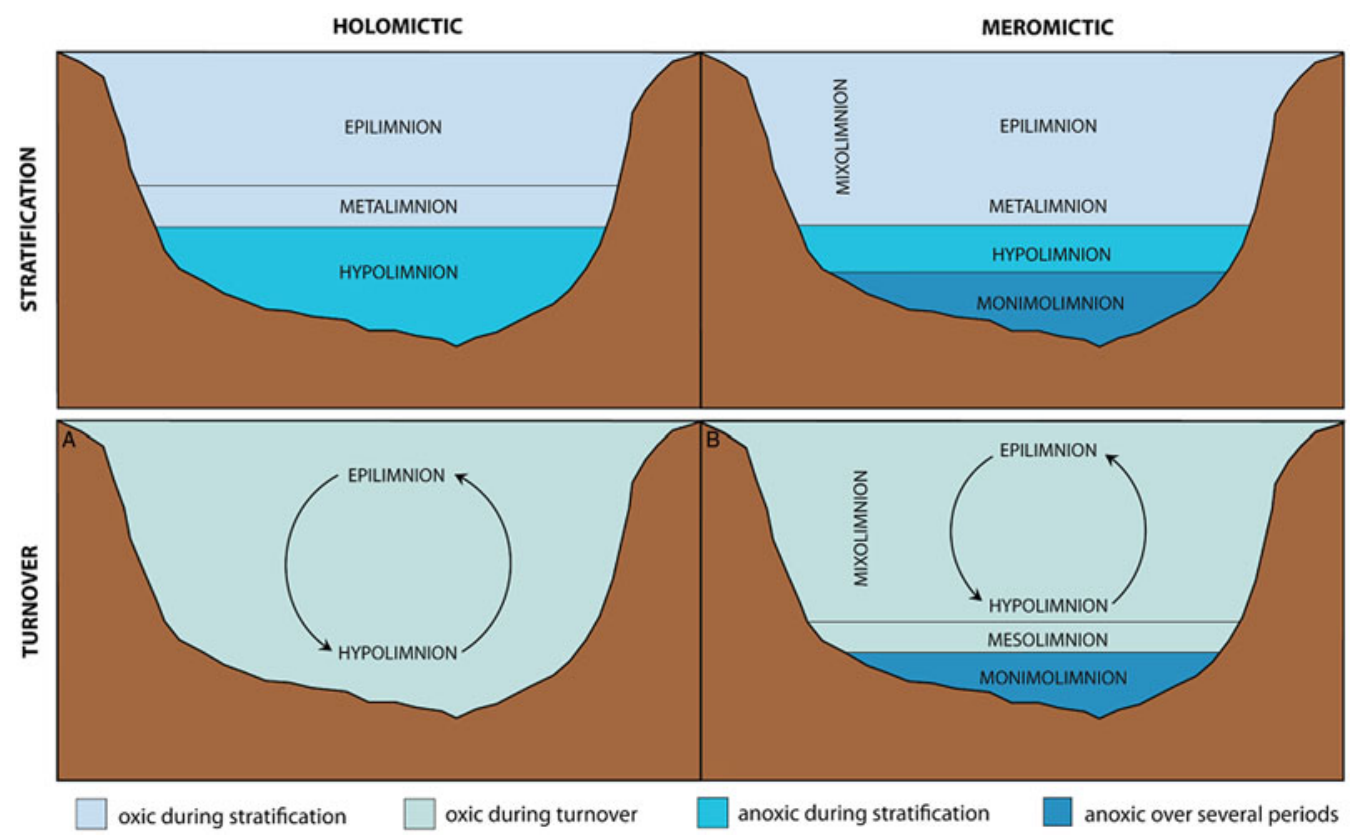

Fig. 3. Patterns of stratification and turnover in holomictic and meromictic lakes.

redox-stratified lakes, either of meromictic or holomictic nature (Fig. 3; for definitions see the following section). In each case, ferruginous conditions can be found in a reducing bottom layer, which is assumed to have been the prevalent feature of the ancient ocean throughout much of the Precambrian and also the Phanerozoic (Zegeye et al. 2012). Two of the lakes Lake Pavin and Lake Matano - are the best studied ferruginous basins with the purpose to transfer gained knowledge to models of the Precambrian ocean. The other three lakes Lake La Cruz, Lake Vechten and Lake Nordbytjernet - were included to our study in order to present lakes with the potential to serve as ancient ocean analogues that have not been investigated as such, yet. By this, we aim to encourage scientists from different disciplines to investigate such environments in order to understand the ancient ocean in detail. Expanding on this unique feature of stratification, we first explain the basic definitions for different lake stratification scenarios in the following section and then compile information on Lake Pavin, Lake Matano, Lake La Cruz, Lake Vechten and Lake Nordbytjernet.

\section{Lake stratification}

Water circulation in lakes is largely controlled by variations in water density at different depths, resulting from seasonal differences in surface temperature and dissolved ions (chemical gradients) (Drever 1997; Boehrer \& Schultze 2008). The topmost layer in a lake, the epilimnion, is exposed to solar radiation, heat-loss by long-wave radiation and thermal contact with the atmosphere. In contrast, the deeper water layer, the hypolimnion, is shielded from major heat sources, and is thus colder than epilimnetic waters. The epi- and hypolimnion are separated from each other by the metalimnion, a zone with a sharp temperature gradient (Andersson 1997). Thus, lakes with sufficient depth tend to be stratified thermally during the warm season (separated into layers of different temperatures). When surface temperatures start exceeding those of the hypolimnion, warmer, more buoyant waters can only be mixed to a depth limited by colder, denser water. During stratification, the epilimnion and atmosphere exchange heat and volatile compounds (such as oxygen) resulting in the physical circulation of epilimnetic waters. Meanwhile, the hypolimnion is insulted from exchange with the atmosphere and thus the oxygen content steadily decreases in these deeper layers due to its consumption via aerobic respiration in the water column. The redox state of the lake differs in the hypo- and epilimnion, separated by a steep gradient of oxygen concentrations in the metalimnion, called oxycline. When epilimnetic temperatures start to decrease (e.g. during autumn) to values approaching hypolimnetic ones, density differences disappear, resulting in the complete vertical mixing of hypo- and epilimnetic waters (fall turnover). During this event, oxygen is mixed into the whole water column and is present at concentrations in equilibrium with air $\mathrm{O}_{2}$ concentrations (Drever 1997). When epilimnetic temperatures reach lower temperatures than hypolimnetic ones (e.g., during winter), density contrasts re-appear and stratification occurs, with a subsequent spring turnover. This phenomenon is observed in regions with seasonal temperature fluctuation, whereas changes in stratification pattern of lakes usually do not occur in areas with constant climate conditions.

Lakes with at least one annual turnover are collectively called holomictic (Fig. 3a). Meromictic lakes in contrast, contain an additional chemically distinct bottom layer, called the monolimnion that has not been recirculated for more than a year (Fig. 3b). This layer is usually anoxic, and overlain by the epi-, meta- and hypolimnion. Seasonal mixing of epi- and hypolimnion result in the mixolimnion. 


\section{Lake Matano}

Lake Matano, the world's largest known ferruginous lake (Crowe et al. 2011), is located on Sulawesi Island, Indonesia $\left(\mathrm{S}^{\circ} 29^{\prime} 9.215^{\prime \prime}, \mathrm{E} 121^{\circ} 22^{\prime} 38.507^{\prime \prime}\right)$. The lake is categorized as meromictic (Crowe et al. 2008c), which results from the combination of its great depth $(>590 \mathrm{~m})$ with the absence of seasonal temperature fluctuations and a steep bathymetry (Crowe et al. 2008b, c). A persistent chemocline at $\sim 100 \mathrm{~m}$ depth divides the lake into an oxic top and an anoxic bottom layer (Crowe et al. 2008c). Although it is not clear when the last mixing of the lake occurred, stable vertical profiles of redoxsensitive elements, such as $\mathrm{Fe}$ and $\mathrm{Mn}$, suggest redox conditions to have prevailed on a millennial time scale (Crowe et al. 2008c). Dissolved Fe(II) is present at concentrations of up to $140 \mu \mathrm{M}$, whereas dissolved $\mathrm{Mn}$ (II) reaches a maximum of $9.5 \mu \mathrm{M}$ in the hypolimnion. Chromium was $180 \mathrm{nM}$ in the epilimnion, but it was not detectable in the hypolimnion. Similarly, sulphate was $20 \mu \mathrm{M}$ in the epilimnion, but was not detectable in the hypolimnion. Instead, trace concentrations of sulphide below $0.2 \mu \mathrm{M}$ were measured below the chemocline (Crowe et al. 2008c) as a result of slow sulphate reduction (Crowe et al. 2008b). Dissolved silica was measured below saturation at 300-420 $\mu \mathrm{M}$ (Crowe et al. 2008b; Zegeye et al. 2012). An additional specific feature of Lake Matano results from the scavenging of phosphate by $\mathrm{Fe}(\mathrm{III})$ (oxyhydr)oxide phases, such as ferrihydrite, which limits primary productivity in the surface-mixed layer. The lack of light-absorbing (in)organic particles in the water column enables light penetration down to a depth of $125 \mathrm{~m}$, where oxygen is already absent. Combined with the supply of $\mathrm{Fe}(\mathrm{II})$, conditions favour the establishment of a large community of anoxygenic phototrophic bacteria, in this particular case green-sulphur bacteria (GSB), at a depth of 115-125 m (Crowe et al. 2008b). The shift from an oxygenic cyanobacteria population in the epilimnion to a community of anoxygenic phototrophs in the hypolimnion is accompanied with a transition in abundances of the photosynthetic pigments chlorophyll $a$ that dominates the oxic waters to a similar quantity of bacteriochlorophyll $e$, which is used by Chlorobiaceae, a family of low-light-adapted GSB. The majority of this family are photolithoautotrophs that use sulphide as an electron donor with the exception of Chlorobium ferrooxidans that uses $\mathrm{Fe}(\mathrm{II})$ instead (Crowe et al. 2008b).

The mineralogy of the mineral particles formed during $\mathrm{Fe}(\mathrm{II})$ oxidation was determined, and showed the presence of carbonated green rust together with magnetite as abundant $\mathrm{Fe}$ minerals below the chemocline (Crowe et al. 2008c; Zegeye et al. 2012). Green rust is a mixed-valence intermediate Fe mineral formed by interaction of $\mathrm{Fe}(\mathrm{III})$ minerals with $\mathrm{Fe}(\mathrm{II})$ (Parmar et al. 2001). Lake Matano is so far the only stratified water body where green rust has been found (Zegeye et al. 2012). Whether the green rust is a microbial product by photoferrotrophy (Kappler \& Newman, 2004) driven by the large GSB community or dissimilatory $\mathrm{Fe}(\mathrm{III})$ reduction (Zegeye et al. 2007) or whether an abiotic solid-phase transformation of ferrihydrite following $\mathrm{Fe}$ (II) adsorption is the pathway for its formation in Lake Matano remains unknown (Zegeye et al. 2012).

\section{Lake Pavin}

Lake Pavin is a meromictic crater lake located $35 \mathrm{~km}$ southwest of Clermont-Ferrand (France) within the youngest volcano in the French Massif Central (N45 29'58.326", E2 ${ }^{\circ} 53^{\prime}$ $\left.12.743^{\prime \prime}\right)$. Surrounded by a $\sim 50 \mathrm{~m}$ high ring of volcanic tuff, the lake is protected from physical mixing by wind. This, in combination with its almost circular geometry $(750 \mathrm{~m}$ diameter, $0.44 \mathrm{~km}^{2}$ surface and $\sim 92 \mathrm{~m}$ maximum depth), results in a persistent redox stratification at a depth of $\sim 60 \mathrm{~m}$ (Aeschbach-Hertig et al. 2002). The depth of the redoxcline can vary due to temporal variations resulting by annual meteorological differences and also was found at $\sim 50 \mathrm{~m}$ depth in 2011 (Cosmidis et al. 2014). The mixolimnion (ca. 0-60 m depth) is oxygenated by seasonal fall and spring turnover, whereas the monimolimnion (ca. 60-92 m depth) remained anoxic for at least the last 100 years and thus reached a steady state (Busigny et al. 2014).

The mineralogy and oxidation state of $\mathrm{Fe}$ in the suspended particles were identified by Cosmidis et al. (2014) at different depths, revealing $\mathrm{Fe}$ to be present mainly in $\mathrm{Fe}(\mathrm{III})$ (oxyhydr) oxides and phyllosilicates at shallower depths, as Fe(II)$\mathrm{Fe}(\mathrm{III})$-phosphate mineral phases near the redoxcline and $\mathrm{Fe}(\mathrm{II})-$ phosphates (vivianite-like) at the lake bottom. Under the reducing conditions in the monimolimnion, dissolved $\mathrm{Fe}(\mathrm{II})$ accumulates to a concentration of up to $1.2 \mathrm{mM}$ (Bura-Nakic et al. 2009). Fe and $\mathrm{Mn}$ colloids (particle size $<0.45 \mu \mathrm{m}$ ) as well as dissolved silica $\left(\mathrm{H}_{4} \mathrm{SiO}_{4}\right)$ and phosphate are present at high concentrations ( $1.1 \mathrm{mM}$ and $340 \mu \mathrm{M}$, respectively) in the bottom layer (Michard et al. 1994). Sulphate exists at low concentrations $(15-20 \mu \mathrm{M})$ in the mixolimnion, and is absent in the monimolimnion (Assayag et al. 2008) as a result of microbial sulphate reduction. This metabolism leads to total dissolved sulphide concentrations between 0.6 and $16.7 \mu \mathrm{M}$ just below the oxycline, with $80 \%$ of it being in colloidal $\mathrm{FeS}$ form as a consequence of $\mathrm{Fe}$ being the dominant metal involved into sulphur redox cycling (Bura-Nakic et al. 2009).

Lehours et al. (2005) identified the microbial community in Lake Pavin over different depths of the water column. They showed an elevated diversity of the archaeal and bacterial communities in samples from anoxic water depths relative to samples from the oxic water layers, with both changing in their structures over different lake depths (Lehours et al. 2005). The largest microbial community is represented by methanogens belonging to the genera Methanosarcinales and Methanomicrobiales, with $71 \%$ of the sequences related to Methanosaeta concilii. At the upper part of the chemocline $(\sim 60 \mathrm{~m})$ sequences were related to methylotrophs as well as to the microaerophilic $\mathrm{Fe}(\mathrm{II})$-oxidizer Gallionella ferruginea (with $97.5 \%$ sequence similarity), suggesting ongoing methane and microaerophilic Fe(II) oxidation at the oxic-anoxic redox transition zone of the lake. At a depth of $90 \mathrm{~m}$, three sequences related to Geothrix fermentans, an Fe(III)-reducing 
$\delta$-Proteobacterium, were observed, suggesting the replenishment of $\mathrm{Fe}(\mathrm{II})$ at lower depths of the lake (Lehours et al. 2007).

\section{Lake La Cruz}

Lake La Cruz is located at an altitude of $1000 \mathrm{~m}$ a.s.1. in the dolomitic karstic 'Serrenia de Cuenca' mountains, near Cuenca, Spain (also called 'Laguna de la Gitana', N39 59' 16.7", E1 ${ }^{\circ} 52^{\prime}$ 25.0") (Rodrigo et al. 2001). Located inside a sink dissolution basin with steep vertical walls rising 20-30 m above the water surface, the lake is protected from wind. In combination with its small surface to depth ratio, it is also persistently stratified for the past four centuries now, however, unlike Lake Matano and Lake Pavin, stratification is not at a constant depth. Depending on the seasonal meteorology of the region within the respective year, its water depth and diameter vary annually. Measurements in 1987 and 1988 revealed variations in the redoxcline depth between 12.8 and $18.7 \mathrm{~m}$. After intense rainfalls in spring 1988, maxima in depth and diameter with 24 and $136 \mathrm{~m}$ were measured, respectively (Rodrigo et al. 2001). This resulted in a sharper and shallower thermocline, as well as a shallower oxic-anoxic boundary relative to periods with lower water levels (Romero-Viana et al. 2010). Nevertheless, the values for iron and sulphide are constant in the anoxic bottom layer at $\sim 900 \mu \mathrm{M}$ and $<3 \mu \mathrm{M}$, respectively. Sulphate is present at $0.05 \mathrm{mM}$ (Rodrigo et al. 2000). One of the lake's main features is the annual summer 'whiting', a shortterm precipitation event whereby calcium carbonate is produced in the water column in sufficient quantities to be visible. The event is caused mainly by increased temperatures and increased $\mathrm{CO}_{2}$ uptake by photosynthetic microorganisms, such that the carbonate crystals appear in light-coloured laminae alternating with dark laminae that result from the precipitation of organic matter throughout the year (Rodrigo et al. 1993).

Romero-Viana et al. (2010) identified photosynthetic pigments in the annual laminated sediment to reconstruct and interpret paleoproductivity in the lake. The study yielded the presence of marker pigments of phototrophic sulphur bacteria, including bacteriochlorophyll $a$, series of bacteriophaeophytin $d$ and the bacterial carotenoids oktenone and chlorobactene (Romero-Viana et al. 2010). Correlating with solar radiation fluxes, the relative abundance of zeaxanthin suggests picocyanobacteria (e.g., Synechococcus sp.), to have dominated primary productivity in Lake La Cruz over the last four centuries (Romero-Viana et al. 2010). This is consistent with the general observation of promoted epicellular calcite precipitation in lakes with abundant picocyanobacteria communities (Romero-Viana et al. 2008). With midday solar fluxes $>1 \mu \mathrm{EM}^{-2} \mathrm{~s}^{-2}$, light penetrates into the upper parts of the anoxic layer of the lake, enabling growth of a population of purple sulphur bacteria (Amoebobacter purpureus) immediately above GSB (Pelodictyon chlatratiforme). A. purpureus is capable of anaerobic photolithotrophy by metabolizing hydrogen sulphide, elemental sulphur and thiosulphate (Eichler and Pfennig, 1988), while P. chlatratiforme is capable of photosynthesis under low-sulphide and low-light conditions (Pfennig \& Cohenbaz 1967).

\section{Lake Nordbytjernet}

Lake Nordbytjernet is located in the Upper Romerike area, $40 \mathrm{~km}$ northeast of Oslo, Norway (N60 9' 23.299", E11 ${ }^{\circ} 9^{\prime}$ $\left.50.9^{\prime \prime}\right)$. The endogenic meromictic kettle lake has a maximum depth of $23 \mathrm{~m}$, a persistent monimolimnion below $20 \mathrm{~m}$ and a surface area of $0.28 \mathrm{~km}^{2}$ (Hongve 2003). The major constituents of the anoxic zone are iron, manganese and phosphate with concentrations reaching up to 710,1180 and $1130 \mu \mathrm{M}$, respectively. Most of the $\mathrm{Fe}$ and $\mathrm{Mn}$ originate from a stream flowing through a forest area that has been artificially drained in modern times. The reducing conditions in the monimolimnion of Lake Nordbytjernet are maintained by the production of organic matter in the trophogenic zone. In contrast to other lakes, sulphate is present at high concentrations (up to $416 \mu \mathrm{M}$ ) in the oxic zone but is depleted in the anoxic bottom (Hongve 2003). According to this author, conditions in Lake Nordbytjernet below $22 \mathrm{~m}$ favour the precipitation of both siderite $\left(\mathrm{FeCO}_{3}\right)$ and vivianite $\left(\mathrm{Fe}_{3}\left(\mathrm{PO}_{4}\right)_{2} \cdot 8 \mathrm{H}_{2} \mathrm{O}\right)$, but played a role in $\mathrm{Fe}$ sedimentation from the monimolimnion. Instead, $\mathrm{Fe}(\mathrm{III})$ (oxyhydr)oxides, dominated by goethite, were the important $\mathrm{Fe}$ compounds in newly formed bottom sediments.

\section{Lake Vechten}

Lake Vechten is a man-made gravel lake located in the municipality of Bunnik, the Netherlands (N52 ${ }^{\circ} 3^{\prime} 40.23^{\prime \prime}$, E5 $^{\circ} 9^{\prime}$ 36.31") that was excavated in 1941 (Steenbergen \& Korthals 1982). It consists of two basins with maximum depths of 11.9 and $10.5 \mathrm{~m}$ and a surface area of $4.7 \mathrm{ha}$, divided by a ridge at about $6 \mathrm{~m}$ depth (Steenbergen \& Verdouw 1982). The lake's water balance is regulated by meteorological conditions and horizontal groundwater flow. Of the five lakes presented here, Lake Vechten is the only holomictic lake with a summer stratification from May until October. A pronounced thermocline separates a cold hypolimnion from a warm epilimnion ( 0 $5 \mathrm{~m}$ ), resulting in hypolimnetic $\mathrm{O}_{2}$ depletion and thus a chemocline just below the thermocline. During summer, Fe(II) and Mn(II) can accumulate at concentrations up to 690 and 180 $\mu \mathrm{M}$ in the reducing bottom layer, respectively. In addition, sulphide concentrations nearly reach millimolar levels just below the oxic-anoxic boundary (Riera et al. 1988), above which sulphate reaches $\sim 400 \mu \mathrm{M}$ (Steenbergen \& Verdouw 1982). Sulphide decreases largely with increasing depth as Fe(II) becomes abundant enough to control sulphide levels (Riera et al. 1988; Verdouw \& Dekkers 1980). Availability of P and Si (52104 and $3-17 \mu \mathrm{M}$, respectively) strongly depends on the fall turnover, with 2- to 5-fold concentrations in the whole mixed water column during winter compared with epilimnetic values during summer.

The deepest light penetration was found during summer stratification with Secchi disc depths of 3.5-4.5 m (extinction coefficients for green $\left(0.38-0.85 \mathrm{~m}^{-1}\right)$, yellow-orange $\left(0.73-0.75 \mathrm{~m}^{-1}\right)$, red $\left(0.73-1.02 \mathrm{~m}^{-1}\right)$ and blue light $\left.\left(0.69-1.42 \mathrm{~m}^{-1}\right)\right)$. Thus, dense populations of phototrophic bacteria establish themselves in the metalimnion and upper hyplomnion where the chemocline starts. According to pigment analyses by Steenbergen \& Korthals (1982) 
the total concentration of chlorophyll is up to $200 \mathrm{mg} \mathrm{m}^{-3}$ during stratification, corresponding to several oxygenic photosynthesizers, including the genera Synechococcus, Chloronema, Chromatium and Thiopedia. At lake depths below $8 \mathrm{~m}$, where light intensities are lower and sulphate concentrations decrease, abundances of sulphide-oxidizing bacteria, such as the families Chlorobiaceae and Chromatiaceae (Steenbergen \& Korthals 1982). A population of brown Chlorobiaceae, mainly Chlorobium phaeobacteroides was found where sulphide was measured at $870 \mu \mathrm{M}$, just beneath a population of green Chlorobiaceae where sulphide concentrations were $<50 \mu \mathrm{M}$. As light extinction occurred mainly at the depths where Synechococcus-type cells and green Chlorobiaceae developed dense communities, brown Chlorobiaceae grew under very lowlight conditions with $0.001 \%$ incident surface light (Riera et al. 1988). As anaerobic bacteria respire low-molecular weight organic carbon compounds, such as acetate and lactate, in the lake sediment as well as the lower hypolimnion layers, fixation of produced $\mathrm{CO}_{2}$ coupled to sulphide oxidation by purple sulphur bacteria at depths below $8 \mathrm{~m}$ is likely (Steenbergen \& Korthals 1982).

\section{Modern stratified lakes as models for Precambrian ocean conditions}

From the presented five stratified lakes, four are meromictic and one, Lake Vechten, possesses a warm-holomixis stratification pattern. Their maximum depths vary greatly with Lake Matano showing the greatest depth $(\sim 590 \mathrm{~m})$ followed by Lake Pavin (92 m), whereas the other three are much shallower with similar depths (between 11.9 and $24.5 \mathrm{~m}$, respectively, Table 2). All five lakes are stratified with regard to dissolved oxygen concentration, resulting in anoxic reduced bottom layers which enable the accumulation of redox-sensitive elements, such as Fe(II). Additionally, Si concentrations in respective bottom layers are relatively high (around $1 \mathrm{mM}$ ) combined with sulphate being almost deficient. Collectively their compositions suggest that all five lakes could serve as analogues for various times in the Archean and Paleoproterozoic.

In terms of the $\mathrm{Fe}(\mathrm{II})$ content, only Lake Matano approximates the estimated upper limit for Archean seawater Fe(II) (given as $120 \mu \mathrm{M}$ by Canfield 2005) (Table 1) with a concentration of $140 \mu \mathrm{M}$ (Table 2). By contrast, the other lakes (with $\mathrm{Fe}$ concentrations between 690 and $1200 \mu \mathrm{M}$ ) significantly exceed Archean estimates (Table 2). In terms of Si, the $420 \mu \mathrm{M}$ in Lake Matano and the $500 \mu \mathrm{M}$ in Lake Nordbytjernet Si (Table 2) are below the suggested Archean Si lower limit of $670 \mu \mathrm{M}$ (Maliva et al. 2005) (Table 1), whereas Lake Pavin and Lake La Cruz contain Si concentrations within the estimated range of Precambrian Si (1100 and $1178 \mu \mathrm{M}$, respectively, Table 2). All five lakes exceed the upper estimate for Archean marine phosphate concentrations $(5.3 \pm 2.6 \mu \mathrm{M}$, Konhauser et al. 2007) (Table 1), with Lake Matano exhibiting the lowest phosphate concentration of $9 \mu \mathrm{M}$, followed by Lake Vechten $(20 \mu \mathrm{M})$, Lake La Cruz $(52.6 \mu \mathrm{M})$, Lake Pavin $(340 \mu \mathrm{M})$ and Lake Nordbytjernet (1130 $\mu \mathrm{M}$, Table 2). Sulphate concentrations are very low in all the lakes with values of $<0.1 \mu \mathrm{M}$ in case of Matano, Pavin and Nordbytjernet, while in Lake La Cruz and Lake Vechten sulphate is present at concentrations of around $\sim 20 \mu \mathrm{M}$ (Table 2), which is low but falls within the range of estimates for the Archean oceans of $200 \mu \mathrm{M}$ (Habicht et al. 2002) to only $80 \mathrm{nM}$ (Crowe et al. 2014) (Table 1).

An important issue to take into account for the evaluation of Lake La Cruz as a model habitat is the annual summer whiting event, a massive calcium carbonate precipitation that likely changes lake geochemistry. This may limit the suitability of Lake La Cruz as a natural laboratory for ancient ocean conditions. In contrast, the geochemical composition of Lake Vechten is quite constant during stratification, which occurs during summer. However, for the evaluation of Lake Vechten as model habitat it is of greater importance to consider its sulphide accumulation to high concentrations of up to $1000 \mu \mathrm{M}$ in the hypolimnion (Table 2). Such high sulphide values are comparable to suggested euxinic conditions in Proterozoic marginal marine settings. Thus, Lake Vechten represents a model habitat for the Proterozoic rather than for the Archean ocean due to the availability of ferruginous and euxinic conditions in its bottom. The simultaneous presence of both dissolved Fe(II) and sulphide is necessary for studying $\mathrm{Fe}-\mathrm{S}$ biogeochemistry in model habitats for the Proterozoic ocean.

When comparing the microbial compositions of the different lakes, it is obvious that anoxygenic phototrophic GSB dominate the microbial communities in ferruginous basins, as is the case with the bottom waters of Lake Matano, Lake La Cruz and Lake Vechten. Anoxygenic photosynthesis is assumed to be an ancient metabolism indicated by the deep branching GSB and green non-sulphur bacteria (GNSB), as well as the utilization of one single photosystem to harvest light energy in contrast to the requirement of two photosystems for oxygenic photosynthesis (Woese 1987; Blankenship 1992). In samples from Lake Matano, the Fe(II)-oxidizing GSB C. ferrooxidans was identified as community member and to date is the only known GSB capable of photoferrotrophy (Heising et al. 1999). Since such GSB need a minimum concentration of $0.8 \mu \mathrm{M}$ free sulphide for sulphide oxidation (Vangemerden 1984), it is likely that in an Fe(II)-rich environment, where sulphide availability was restricted to hydrothermal vents as in the Archean ocean, their preferred electron donor was Fe(II). In photic environments, where $\mathrm{Fe}(\mathrm{II})$ oxidation and $\mathrm{Fe}$ (III) mineral precipitation takes place, phosphorus was less available due to scavenging by $\mathrm{Fe}$ (III) (oxyhydr)oxides, and GSB further are suggested to have been the most active primary producing metabolism by photosynthetic C-fixation before cyanobacteria evolved confirmed by primary production rates of $3.8 \times 10^{-3}$ mol $\mathrm{C} \mathrm{m}^{-2}$ day $^{-1}$ by photosynthetic $\mathrm{C}$ fixation in Lake Matano (Crowe et al. 2008b).

It is conceivable that the oxidation of hydrothermally derived $\mathrm{Fe}(\mathrm{II})$ and $\mathrm{H}_{2} \mathrm{~S}$ in the photic zone to sulphate and $\mathrm{Fe}(\mathrm{III})$ by GSB and GNSB, respectively, facilitated the activities of already evolved anaerobic sulphate- as well as $\mathrm{Fe}(\mathrm{III})$-respiring bacteria in deeper layers of the water column. Chemoorganotrophic metabolisms were further facilitated by the formation of organic carbon by $\mathrm{CO}_{2}$ fixation driven by oxygenic photosynthesis as cyanobacteria likely evolved around 3.0 
Table 2. Comparison of five holo- or meromictic lakes regarding their physical and chemical properties

\begin{tabular}{|c|c|c|c|c|c|c|c|c|c|c|}
\hline \multirow{3}{*}{$\begin{array}{l}\text { Stratification } \\
\text { Layer }\end{array}$} & \multirow{2}{*}{\multicolumn{2}{|c|}{$\frac{\text { Lake Matano }}{\text { Meromixis }^{1}}$}} & \multirow{2}{*}{\multicolumn{2}{|c|}{$\frac{\text { Lake Pavin }}{\text { Meromixis }^{5}}$}} & \multirow{2}{*}{\multicolumn{2}{|c|}{$\frac{\text { Lake La Cruz }}{\text { Meromixis }^{8}}$}} & \multirow{2}{*}{\multicolumn{2}{|c|}{$\frac{\text { Lake Nordbytjernet }}{\text { Meromixis }^{9}}$}} & \multirow{2}{*}{\multicolumn{2}{|c|}{$\frac{\text { Lake Vechten }}{\text { Monomixis }^{10}}$}} \\
\hline & & & & & & & & & & \\
\hline & Oxic & Anoxic & Oxic & Anoxic & Oxic & Anoxic & Oxic & Anoxic & Oxic & Anoxic \\
\hline depth (m) & $0-120^{1}$ & $120-590^{1}$ & $0-60^{5}$ & $61-92^{5}$ & $0-12 / 18^{8}$ & $12 / 18-24.5^{8}$ & $0-18 / 21^{9}$ & $18 / 21-23^{9}$ & $0-6^{10}$ & $6 / 7-11.9^{10}$ \\
\hline $\mathrm{Fe}(\mathrm{II})(\mu \mathrm{M})$ & $0^{1}$ & $140^{1}$ & $0^{5}$ & $>1200^{5}$ & $0-10^{8}$ & $10-1000^{8}$ & $<0.5^{9}$ & $714^{9}$ & $0^{10}$ & $690^{10}$ \\
\hline $\mathrm{Mn}^{2+}(\mu \mathrm{M})$ & $0.45^{2}$ & $9.5^{3}$ & $<27^{5}$ & $<7^{5}$ & n.a. & n.a. & $0.7^{9}$ & $1180^{9}$ & $0^{10}$ & $180^{10}$ \\
\hline $\mathrm{PO}_{4}^{3-}(\mu \mathrm{M})$ & $<0.025^{1}$ & $9^{1}$ & $0^{5}$ & $340^{5}$ & $0.1^{8}$ & $52.6^{8}$ & $0^{9}$ & $1130^{9}$ & $52-104^{10}$ & $20^{10}$ \\
\hline $\mathrm{SO}_{4}^{2-}(\mu \mathrm{M})$ & $<20^{1}$ & $<0.1^{1}$ & $<20^{6}$ & $0^{6}$ & $31.2^{8}$ & $20.8^{8}$ & $416^{9}$ & $0^{9}$ & $400^{10}$ & $20^{10}$ \\
\hline $\mathrm{S}^{2-}(\mu \mathrm{M})$ & $0^{1}$ & $<0.2^{1}$ & $0^{6}$ & $<16.7^{6}$ & $1-3^{8}$ & $>15^{8}$ & n.a. & n.a. & n.a. & $<1000^{10}$ \\
\hline Mo $(\mu \mathrm{M})$ & n.a. & n.a. & $>0.4^{5}$ & $<0.8^{5}$ & n. a. & n. a. & n.a. & n.a. & n.a. & n.a. \\
\hline $\mathrm{Cr}(\mu \mathrm{M})$ & $\sim 0.18^{3}$ & $<0.03^{3}$ & n.a. & n.a. & n. a. & n. a. & n.a. & n.a. & n.a. & n.a. \\
\hline $\mathrm{SiO}_{2(\mathrm{ag})}(\mu \mathrm{M})$ & $300^{1}$ & $420^{1}$ & $0^{5}$ & $1100^{5}$ & $10.4^{8}$ & $1178.6^{8}$ & $<107.1^{9}$ & $500^{9}$ & $3.6-17.9^{10}$ & n.a. \\
\hline $\mathrm{pH}$ & $8.6^{1}$ & $7.0^{1}$ & $6.2-8.5^{7}$ & $6.0-6.2^{7}$ & $8.3-8.7^{8}$ & $6.6-7.5^{8}$ & $7.0-8.2^{9}$ & $7.0-7.9^{9}$ & $6.3-7.2^{10}$ & $6.1-6.3^{10}$ \\
\hline $\mathrm{T}\left({ }^{\circ} \mathrm{C}\right)$ & $25-28^{1}$ & $25-28^{1}$ & $<17^{7}$ & $<6^{7}$ & $6-24^{8}$ & $6-6.2^{8}$ & $3.6-22^{9}$ & $3.7-3.9^{9}$ & $20-24^{10}$ & $4-5^{10}$ \\
\hline
\end{tabular}

n.a. $=$ not available.

${ }^{1}$ Crowe et al. (2008b)

${ }^{2}$ Crowe et al. (2011)

${ }^{3}$ Crowe et al. (2008c)

${ }^{4}$ Crowe et al. (2008a)

${ }^{5}$ Busigny et al. (2014)

${ }^{6}$ Bura-Nakic et al. (2009)

${ }^{7}$ Cosmidis et al. (2014)

${ }^{8}$ Rodrigo et al. (2001)

${ }^{9}$ Hongve (1994)

${ }^{10}$ Riera et al. (1988)

Ga (Crowe et al. 2013; Planavsky et al. 2014). However, sulphate reduction rates were quantified to be low but still sufficient to remove all sulphate $(<20 \mu \mathrm{M}$ in the mixed layer, $<0.1 \mu \mathrm{M}$ in the bottom layer) in the water column of Lake Matano. Unlike Lake Matano, Lake La Cruz and Lake Vechten, the microbial community in Lake Pavin consists mainly of methylotrophs and microaerophilic $\mathrm{Fe}(\mathrm{II})$-oxidizers in the upper water layers, whereas methanogens and Fe(III)-reducers dominate the monimolimnion (Lehours et al. 2005).

\section{Alternative field sites for studying Archean and Proterozoic ocean conditions}

In addition to the five lakes described above, there are two examples of ferruginous lakes that have not been very well studied with respect to their biogeochemical properties so far but also provide conditions similar to those described for the other five lakes: Brownie Lake in Minnesota, USA (N44 ${ }^{\circ}$ 58' 4.483", W93 ${ }^{\circ} 1^{\prime}$ 26.677") (Swain 1984; Myrbo et al. 2011) and Canyon Lake in Michigan, USA (N46 49' 58.069", W87 55' 14.858") (Smith 1940; Davis 1981; Anderson-Carpenter et al. 2011). These lakes are redox-stratified and host ferruginous conditions with $\mathrm{Fe}(\mathrm{II})$ concentrations of $1500 \mu \mathrm{M}$ in Brownie Lake and $857 \mu \mathrm{M}$ in Canyon Lake, respectively. Both lakes are small with maximum depths of $\sim 15$ and $25 \mathrm{~m}$, respectively, compared with the well-studied field sites Lake Matano and Lake Pavin.

Furthermore, there are lakes with sulphidic bottom layers such as Green Lake in New York, USA (N43 $3^{\prime}$ 5.965", ${\mathrm{W} 75^{\circ}}^{\circ} 57^{\prime}$ 57.226") (Suits \& Wilkin 1998) and Lago Di Cadagno in the Swiss Alps (N46 33' 2.246", E8 ${ }^{\circ} 42^{\prime}$ 42.923") (Canfield et al. 2010), which both are not ferruginous since dissolved $\mathrm{Fe}$ (II) readily is scavenged by the sulphide and precipitates in form of iron sulphides in the water column. However, both lakes are subject of research projects already and contributed to the reconstruction of the ancient microbial sulphur cycle by analyses of the sulphur isotope compositions and contributions of microbial activities to the specific fractionation patterns (Suits \& Wilkin 1998; Canfield et al. 2010). Nevertheless, it remains unknown to which extent the iron cycle is coupled to the sulphur cycle in habitats that contain both $\mathrm{Fe}$ - and $\mathrm{S}$-species, including questions on how bacterial abundances are spatially and temporally distributed and on which levels respective types of bacteria interact or compete for certain electron donors (Fe(II), sulphide, organic $\mathrm{C}$ ) and electron acceptors (Fe(III), sulphate, nitrate). Since the holomictic Lake Vechten provides the presence of both, reduced Fe- and $\mathrm{S}$-species at the same time, its investigation as modern model for Proterozoic oceans could improve our understanding of early biogeochemical $\mathrm{Fe}$ - and S-turnover and the coupling of these two cycles remarkably. One of the future challenges will be to find further habitats that are rich in Fe and $\mathrm{S}$ to evaluate and verify the observations from Lake Vechten. Such Feand S-rich habitats do not necessarily need to be stratified lakes but simply have to provide the simultaneous presence of dissolved $\mathrm{Fe}$ (II) and sulphide. One example for such a habitat is the Arvadi Spring, located in the higher Engadin window of the eastern Swiss Alps (N46 40' 14.074", E9 39' 52.956") within the Albula valley in the Canton of Grisons (Strauss et al. 2015). As one of several sulphur-containing springs of the area, the Arvadi spring stands out from the other springs by the presence of Fe- and S-species at tens of $\mu \mathrm{M}$ concentrations at the same time. Waters from two separate springs, namely the 


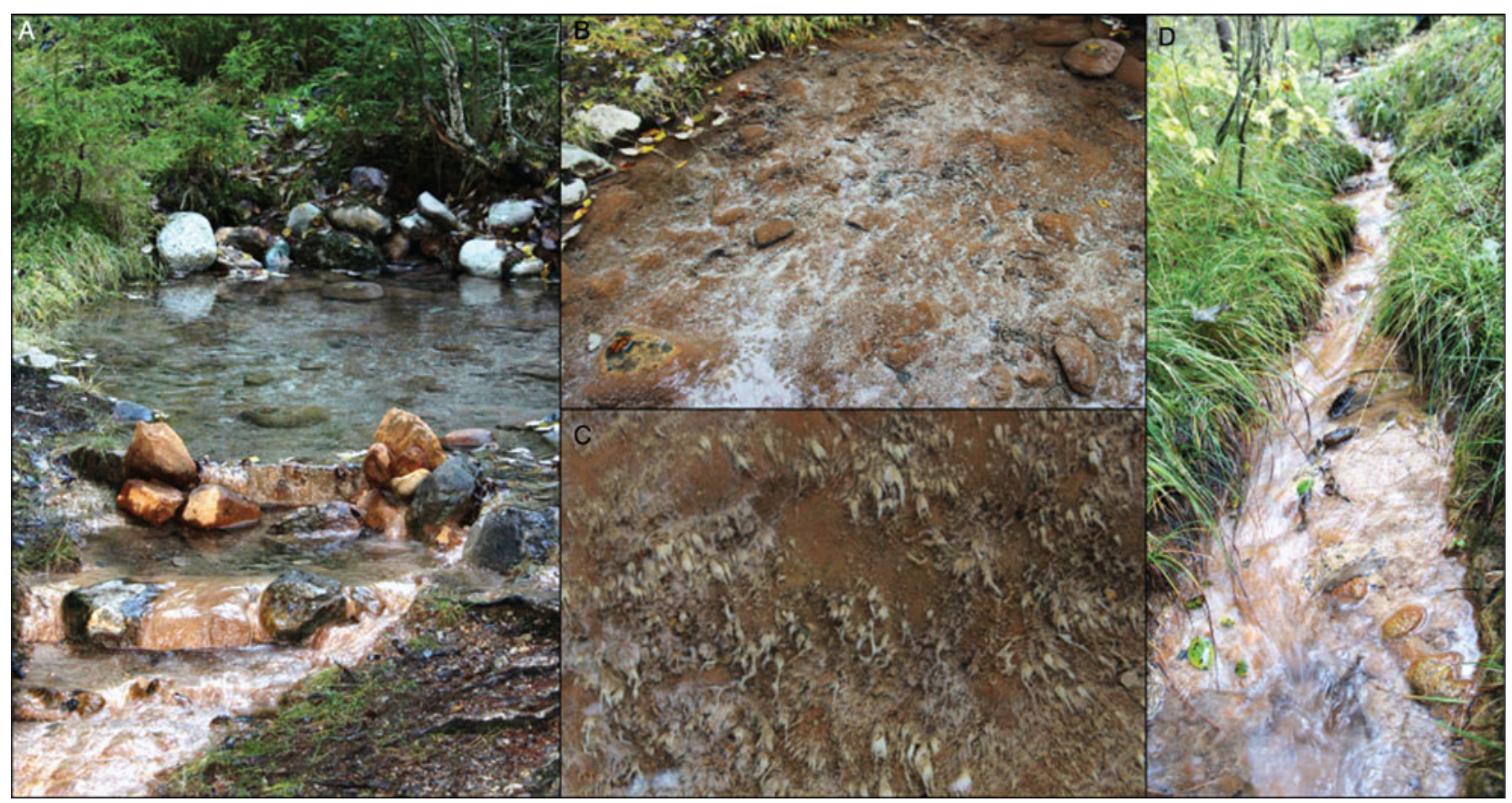

Fig. 4. The Fe- and S-rich Arvadi Spring, located in the eastern Swiss Alps. Photograph was taken in February 2014. (a) Front view of the spring with the spring pond in the back and creek outflow. (b) View on the spring front from the top. The white $S^{0}$ flocks are distributed all over the spring pond, overlaying reddish Fe(III) minerals in the spring sediment. (c) White biofilms of Thiothrix like bacteria sticking to stones at the creek outflow are a strong indication for the presence of sulphide-oxidizing bacteria in the spring. (d) Spring creek flows downwards into forest.

sulphide-containing Zuelper spring and a $\mathrm{Fe}(\mathrm{II})$-containing spring, is mixed, resulting in the mixed Arvadi Spring water (Koeksoy, unpublished data). The spring is characterized by a distinct smell of sulphide and sediments of reddish colour, indicating the presence of $\mathrm{Fe}(\mathrm{III})$ (oxyhydr)oxides, covered with whitish flocks consisting probably of elemental sulphur (Fig. 4). Additionally, whitish biofilms cover parts of the spring sediment and most probably contain sulphide-oxidizing bacteria such as Thiothrix spp. that store $\mathrm{S}^{0}$ in their cells (Kurt Hanselmann, personal communication). Identification of the $\mathrm{S}^{0}$ sulphur isotopic composition revealed a depletion in ${ }^{34} \mathrm{~S}$ with $\delta^{34} \mathrm{~S}$ values between -26 and $-23 \%$, suggesting dissolved sulphide to be generated by microbial reduction of sulphate that was quantified at high concentrations up to $10.4 \mathrm{mM}$ (Strauss et al. 2015). The source of sulphate is assumed to be the dissolution of evaporitic gypsum that is overlain by the Silvretta nappe crystalline rocks on which the Albula valley is based on. Associated with a minor isotope effect, microbial oxidation of sulphide is suggested to occur at the oxic-anoxic redox boundary, also being the likely source of $\mathrm{S}^{0}$ flocks (Strauss et al. 2015). The spring is currently evaluated for its suitability as Proterozoic ocean model by the identification of its microbial community and geochemical composition and promises a high chance to achieve a better understanding of Proterozoic FeS biogeochemistry. First results of Most Probable Number studies on sediment samples from the spring identified microaerophiles to be the most abundant $\mathrm{Fe}$ - and S-metabolizing bacteria (Koeksoy and Kappler, unpublished data) which is in accordance to what is assumed for the Proterozoic ocean due to the formation of a redox transition zone in surface water layers after the GOE. As the oxygen content of the spring water is high being close to saturation of $100 \%$, anaerobic phototrophic and chemolithotrophic Feand S-metabolizing bacteria were quantified at lower cell numbers and thus are concluded to colonize only deeper and thus oxygen-depleted layers of the spring sediment. Further evaluation of microbial activities and interactions are ought to be identified with current experiments with the major goal of gaining a better understanding of spatial and temporal interactions of the Fe- and S-cycles on the microbial as well the geochemical levels.

\section{Outlook and future research needs}

The investigation of Precambrian environment-biosphere feedback systems to understand BIF deposition relies largely on circumstantial evidence to piece together an accurate picture of the functioning of ancient marine ecosystems. Our research approach must necessarily be multidisciplinary in this regard. While information obtained from the Precambrian rock record of BIF sets the relevant geochemical parameters and laboratory experiments allow us to manipulate conditions in order to observe the effect of a set number of variables on processes relevant for BIF deposition, modern environments act as natural laboratories allowing us to observe the processes relevant for BIF deposition in situ. Therefore, there is need for well-suited natural habitats that provide conditions similar to those on ancient Earth. Limited by the presence of specific features such as anoxic conditions as well as the presence of high $\mathrm{Fe}(\mathrm{II})$ concentrations, only a handful of lakes make suitable 
models for the ancient ocean. The two lakes that are currently used as modern analogues namely Lake Matano and Lake Pavin, are good but maybe not ideal, since they are diverging from estimated ancient seawater conditions in some aspects, such as high phosphate concentrations as well as probably too high $\mathrm{Fe}(\mathrm{II})$ concentrations relative to estimated ranges of respective compounds in Archean seawater. Alternatively, potential is hidden in Lake Vechten, Lake Nordbytjernet, Brownie Lake and Canyon Lake, all ferruginous lakes that were not considered enough as model habitats so far. These lakes could be examined in more detail in the future, in order to compile insights comparable with those gained in the numerous studies of Lake Matano and Lake Pavin. The main challenge of our scientific community still is to find alternative habitats that also provide appropriate, and ideally, optimal conditions with parameters within the ranges delineated by the Precambrian rock record. However, more important than evaluating each habitat as an individual model for the ancient ocean is to connect the different aspects that we attain from each habitat and to transfer them to our current models of the Precambrian oceans and their biogeochemical processes. As there will never be the perfect model field site and as our view on ancient ocean conditions changes constantly, we will benefit most by answering different questions using appropriate individual model habitats.

\section{Acknowledgements}

The authors would like to thank H. Strauss (Muenster), K. Hanselmann (Zuerich) and R. Schoenberg/G. Albut (Tuebingen) for our collaboration studying the Arvadi spring. E.K. and M.H. are supported by the German Research Foundation (DFG) grants (numbers KA 1736/ 24-1 and KA1736/27-1). We also would like to thank A. Mloszewska for helpful comments and manuscript revisions.

\section{References}

Aeschbach-Hertig, W., Hofer, M., Schmid, M., Kipfer, R. \& Imboden, D.M. (2002). The physical structure and dynamics of a deep, meromictic crater lake (Lac Pavin, France). Hydrobiologia 487, 111-136.

Andersson, C. (1997). Transfer function vs. modern analog technique for estimating Pliocene sea-surface temperatures based on planktic foraminiferal data, western equatorial Pacific Ocean. J. Foraminiferal Res. 27, 123-132.

Anderson-Carpenter, L.L., McLachlan, J.S., Jackson, S.T., Kuch, M., Lumibao, C.Y. \& Poinar, H.N. (2011). Ancient DNA from lake sediments: bridging the gap between paleoecology and genetics. BMC Evolutionary Biology 11, 30.

Assayag, N., Jezequel, D., Ader, M., Viollier, E., Michard, G., Prevot, F. \& Agrinier, P. (2008). Hydrological budget, carbon sources and biogeochemical processes in Lac Pavin (France): constraints from delta O-18 of water and delta C-13 of dissolved inorganic carbon. Appl. Geochem. 23, 2800-2816.

Bjerrum, C.J. \& Canfield, D.E. (2002). Ocean productivity before about 1.9 Gyr ago limited by phosphorus adsorption onto iron oxides. Nature 417, $159-162$.
Blankenship, R.E. (1992). Origin and early evolution of photosynthesis. Photosynth. Res. 33, 91-111.

Boehrer, B. \& Schultze, M. (2008). Stratification of lakes. Rev. Geophys. 46. Bura-Nakic, E., Viollier, E., Jezequel, D., Thiam, A. \& Ciglenecki, I. (2009). Reduced sulfur and iron species in anoxic water column of meromictic crater Lake Pavin (Massif Central, France). Chem. Geol. 266, 311-317.

Busigny, V., Planavsky, N.J., Jezequel, D., Crowe, S., Louvat, P., Moureau, J., Viollier, E. \& Lyons, T.W. (2014). Iron isotopes in an Archean ocean analogue. Geochim. Cosmochim. Acta 133, 443-462.

Canfield, D.E. (1998). A new model for Proterozoic ocean chemistry. Nature 396, $450-453$.

Canfield, D.E. (2005). The early history of atmospheric oxygen: homage to Robert M. Garrels. Annu. Rev. Earth Planet. Sci. 33, 1-36.

Canfield, D.E., Farquhar, J. \& Zerkle, A.L. (2010). High isotope fractionations during sulfate reduction in a low-sulfate euxinic ocean analog. Geology 38, 415-418.

Cloud, P. (1973). Paleoecological significance of the banded iron-formation. Econ. Geol. 68, 1135-1143.

Conkright, M.E., Gregg, W.W. \& Levitus, S. (2000). Seasonal cycle of phosphate in the open ocean. Deep-Sea Research 47, 159-175.

Cosmidis, J., Benzerara, K., Morin, G., Busigny, V., Lebeau, O., Jezequel, D., Noel, V., Dublet, G. \& Othmane, G. (2014). Biomineralization of iron-phosphates in the water column of Lake Pavin (Massif Central, France). Geochim. Cosmochim. Acta 126, 78-96.

Craddock, P.R. \& Dauphas, N. (2011). Iron and carbon isotope evidence for microbial iron respiration throughout the Archean. Earth Planet. Sci. Lett. 303(1), 121-132.

Crowe, S.A., Fowle, D.A., Katsev, S., Sundby, B., Mucci, A. \& Haffner, G. D. (2008a). Geochemistry of Mo in a modern Archean ocean analogue. Geochim. Cosmochim. Acta 72, A190-A190.

Crowe, S.A., Jones, C., Katsev, S., Magen, C., O’Neill, A.H., Sturm, A., Canfield, D.E., Haffner, G.D., Mucci, A., Sundby, B. et al. (2008b). Photoferrotrophs thrive in an Archean Ocean analogue. Proc. Natl. Acad. Sci. USA 105, 15938-15943.

Crowe, S.A., O’Neill, A.H., Katsev, S., Hehanussa, P., Haffner, G.D., Sundby, B., Mucci, A. \& Fowle, D.A. (2008c). The biogeochemistry of tropical lakes: a case study from Lake Matano, Indonesia. Limnol. Oceanogr. 53, 319-331.

Crowe, S.A., Katsev, S., Leslie, K., Sturm, A., Magen, C., Nomosatryo, S., Pack, M.A., Kessler, J.D., Reeburgh, W.S., Roberts, J.A. et al. (2011). The methane cycle in ferruginous Lake Matano. Geobiology 9, 61-78.

Crowe, S.A., Dossing, L.N., Beukes, N.J., Bau, M., Kruger, S.J., Frei, R. \& Canfield, D.E. (2013). Atmospheric oxygenation three billion years ago. Nature 501, 535-538.

Crowe, S.A., Paris, G., Katsev, S., Jones, C., Kim, S.-T., Zerkle, A.L., Nomosatryo, S., Fowle, D.A., Adkins, J.F. \& Sessions, A.L. (2014). Sulfate was a trace constituent of Archean seawater. Science 346, 735-739.

Czaja, A.D., Johnson, C.M., Beard, B.L., Roden, E.E., Li, W. \& Moorbath, S. (2013). Biological $\mathrm{Fe}$ oxidation controlled deposition of banded iron formation in the ca. $3770 \mathrm{Ma}$ Isua Supracrustal Belt (West Greenland). Earth Planet. Sci. Lett. 363, 192-203.

Davis, M.B. (1981). Outbreaks of forest pathogens in Quaternary history. Proc. IV Int. Palynological Conf., Lucknow, vol. 3, 216-226.

DeMaster, D.J., Leynaert, A. \& Queguiner, B. (1995). The silica balance in the world ocean: a reestimate. Science 268, 375-379.

Drever, J.I. (1997). The geochemistry of natural waters: surface and groundwater environments. Prentice Hall, Eaglewood Cliffs, New Jersey, USA.

Eichler, B. \& Pfenning, N. (1988). A new purple sulfur bacterium from stratified fresh-water lakes, Amoebobacter-Purpureus Sp-Nov. Archives of Microbiology 149, 395-400.

Eickhoff, M., Obst, M., Schröder, C., Hitchcock, A.P., Tyliszczak, T., Martinez, R.E., Robbins, L.J., Konhauser, K.O. and Kappler, A. (2014). Nickel partitioning in biogenic and abiogenic ferrihydrite: the influence of silica and implications for ancient environments. Geochim. Cosmochim. Acta 140, 65-79.

Gole, M.J. \& Klein, C. (1981). Banded iron-formations through much of the Precambrian time. J. Geol 89, 169-183. 
Grotzinger, J.P. \& Kasting, J.F. (1993). New constraints on Precambrian ocean composition. J. Geol 101, 235-243.

Habicht, K.S., Gade, M., Thamdrup, B., Berg, P. \& Canfield, D.E. (2002). Calibration of sulfate levels in the Archean ocean. Science 298, 2372-2374.

Heising, S., Richter, L., Ludwig, W. \& Schink, B. (1999). Chlorobium ferrooxidans sp. nov., a phototrophic green sulfur bacterium that oxidizes ferrous iron in coculture with a "Geospirillum" sp strain. Archives of Microbiology 172, 116-124.

Holland, H.D. (1973). The oceans; a possible source of iron in iron-formations. Econ. Geol. 68, 1169-1172.

Holland, H.D. (2006). The oxygenation of the atmosphere and oceans. Phil. Trans. R. Soc. B-Biol. Sci. 361, 903-915.

Holm, N.G. (1989). The 13C12C ratios of siderite and organic matter of a modern metalliferous hydrothermal sediment and their implications for banded iron formations. Chem. Geol. 77, 41-45.

Hongve, D. (1994). Nutrient Metabolism (C, N, P, and Si) in the Trophogenic Zone of a Meromictic Lake. Hydrobiologia 277, 17-39.

Hongve, D. (2003). Chemical stratigraphy of recent sediments from a depth gradient in a meromictic lake, Nordbytjernet, SE Norway, in relation to variable external loading and sedimentary fluxes. J. Paleolimnol. 30, 75-93.

Johnson, C.M., Beard, B.L. \& Roden, E.E. (2008). The iron isotope fingerprints of Redox and biogeochemical cycling in modern and ancient earth. Annu. Rev. Earth Planet. Sci. 36, 457-493.

Jones, C., Nomosatryo, S., Crowe, S.A., Bjerrum, C.J., \& Canfield, D.E. (2015). Iron oxides, divalent cations, silica, and the early earth phosphorus crisis. Geology 48, 135-138.

Jorgensen, B.B. (1982). Mineralization of organic-matter in the sea bed - the role of sulfate reduction. Nature 296, 643-645.

Kappler, A. \& Newman, D.K. (2004). Formation of Fe(III)-minerals by $\mathrm{Fe}(\mathrm{II})$-oxidizing photoautotrophic bacteria. Geochimica et Cosmochimica Acta 68, 1217-1226.

Kappler, A., Pasquero, C., Konhauser, K.O. \& Newman, D.K. (2005). Deposition of banded iron formations by anoxygenic phototrophic $\mathrm{Fe}$ (II)-oxidizing bacteria. Geology 33, 865-868.

Klein, C. and Beukes, N.J. (1992). Time distribution, stratigraphy, and sedimentologic setting, and geochemistry of Precambrian iron-formations. In: The Proterozoic Biosphere: A Multidisciplinary Study. ed. William Schopf, J. \& Klein, C., Cambridge University Press, Cambridge, pp. 139-146.

Klein, C. (2005). Some Precambrian banded iron-formations (BIFs) from around the world: their age, geologic setting, mineralogy, metamorphism, geochemistry, and origin. Am. Mineral. 90, 1473-1499.

Köhler, I., Konhauser, K.O., Papineau, D., Bekker, A. \& Kappler, A. (2013). Biological carbon precursor to diagenetic siderite with spherical structures in iron formations. Nat. Commun. 4, 1741.

Konhauser, K.O., Hamade, T., Raiswell, R., Morris, R.C., Ferris, F.G., Southam, G. \& Canfield, D.E. (2002). Could bacteria have formed the Precambrian banded iron formations? Geology 30, 1079-1082.

Konhauser, K.O., Newman, D.K. \& Kappler, A. (2005). The potential significance of microbial $\mathrm{Fe}(\mathrm{III})$ reduction during deposition of Precambrian banded iron formations. Geobiology 3, 167-177.

Konhauser, K.O., Lalonde, S.V., Amskold, L. \& Holland, H.D. (2007). Was there really an Archean phosphate crisis? Science 315, 1234-1234.

Konhauser, K.O., Pecoits, E., Lalonde, S.V., Papineau, D., Nisbet, E.G., Barley, M.E., Arndt, N.T., Zahnle, K. \& Kamber, B.S. (2009). Oceanic nickel depletion and a methanogen famine before the Great Oxidation Event. Nature 458, 750-753.

Lehours, A.C., Bardot, C., Thenot, A., Debroas, D. \& Fonty, G. (2005). Anaerobic microbial communities in Lake Pavin, a unique meromictic lake in France. Appl. Environ. Microbiol. 71, 7389-7400.

Lehours, A.C., Evans, P., Bardot, C., Joblin, K. and Gérard, F. (2007). Phylogenetic diversity of Archea and bacteria in the Anoxic Zone of a meromictic Lake (Lake Pavin, France). Appl. Environ. Microbiol. 73, 2016-2019.

Maliva, R.G., Knoll, A.H. \& Simonson, B.M. (2005). Secular change in the Precambrian silica cycle: insights from chert petrology. Geol. Soc. Am. Bull. 117, 835-845.
Michard, G., Viollier, E., Jézéquel, D. \& Sarazin, G. (1994). Geochemical study of a crater lake: Pavin Lake, France - identification, location and quantification of the chemical reactions in the lake. Chem. Geol. 115, 103-115.

Mloszewska, A.M., Pecoits, E., Cates, N.L., Mojzsis, S.J., O’Neil, J., Robbins, L.J. \& Konhauser, K.O. (2012). The composition of Earth's oldest iron formations: the Nuvvuagittuq Supracrustal Belt (Québec, Canada). Earth Planet. Sci. Letters 317, 331-342.

Morris, R.C. (1993). Genetic modelling for banded iron-formation of the Hamersley Group, Pilbara Craton, Western Australia. Precambr. Res. 60, 243-286.

Myrbo, A., Murphy, M. and Stanley, V. (2011). The Minneapolis Chain of Lakes by bicycle: glacial history, human modifications, and paleolimnology of an urban natural environment. Field Guides 24, 425-437.

Parmar, N., Gorby, Y.A., Beveridge, T.J. \& Ferris, F.G. (2001). Formation of green rust and immobilization of nickel in response to bacterial reduction of hydrous ferric oxide. Geomicrobiol. J. 18, 375-385.

Partin, C.A., Lalonde, S.V., Planavsky, N.J., Bekker, A., Rouxel, O.J., Lyons, T.W. \& Konhauser, K.O. (2013). Uranium in iron formations and the rise of atmospheric oxygen. Chem. Geol. 362, 82-90.

Pecoits, E., Smith, M.L., Catling, D.C., Philippot, P., Kappler, A. \& Konhauser, K.O. (2015). Atmospheric hydrogen peroxide and Eoarchean iron formations. Geobiology 13, 1-14.

Pfennig, N. \& Cohenbaz, G. (1967). Some properties of Green Bacterium Pelodictyon clathratiforme. Arch. Mikrobiol. 59, 226.

Planavsky, N.J., Reinhard, C.T., Wang, X., Thomson, D., McGoldrick, P., Rainbird, R.H., Johnson, T., Fischer, W.W. \& Lyons, T.W. (2014). Low Mid-Proterozoic atmospheric oxygen levels and the delayed rise of animals. Science 346, 635-638.

Posth, N.R., Hegler, F., Konhauser, K.O. \& Kappler, A. (2008). Alternating $\mathrm{Si}$ and $\mathrm{Fe}$ deposition caused by temperature fluctuations in Precambrian oceans. Nat. Geosci. 1, 703-708.

Posth, N.R. et al. (2013a). Simulating Precambrian banded iron formation diagenesis. Chem. Geol. 362, 66-73.

Posth, N.R., Konhauser, K.O. \& Kappler, A. (2013b). Microbiological processes in banded iron formation deposition. Sedimentology $\mathbf{6 0}$, 1733-1754.

Posth, N.R., Canfield, D.E. \& Kappler, A. (2014). Biogenic Fe(III) minerals: from formation to diagenesis and preservation in the rock record. Earth-Sci. Rev. 135, 103-121.

Rasmussen, B., Krapež, B. \& Muhling, J.R. (2015). Seafloor silicification and hardground development during deposition of $2.5 \mathrm{Ga}$ banded iron formations. Geology 43, 235-238.

Riera, X.G., Garcia-Gil, L.J. \& Abella, C.A. (1988). Lake Vechten, Schleinsee and Buchensee as examples of west central European holomictic lakes containing phototrophic bacteria. Sci. Gerundensis 14, 57-69.

Robbins, L.J., Lalonde, S., Saito, M.A., Planavsky, N., Mloszewska, A., Pecoits, E., Scott, C., Dupont, C., Kappler, A. \& Konhauser, K. (2013). Authigenic iron oxide proxies for marine zinc over geological time and implications for eukaryotic metallome evolution. Geobiology 11, 295-306.

Robbins, L.J., Swanner, E.D., Lalonde, S.V., Eickhoff, M., Paranich, M.L., Reinhard, C.T., Peacock, C.L., Kappler, A. \& Konhauser, K.O. (2015). Limited $\mathrm{Zn}$ and Ni mobility during simulated iron formation diagenesis. Chem. Geol. 402, 30-39.

Rodrigo, M., Vicente, E. \& Miracle, M. (1993). Short-term calcite precipitation in the karstic meromictic Lake La Cruz (Cuenca, Spain). Int. Vereinigung Theor. Angew. Limnol. Verh. 25, 711-719.

Rodrigo, M.A., Vicente, E. \& Miracle, M.R. (2000). The role of light and concentration gradients in the vertical stratification and seasonal development of phototrophic bacteria in a meromictic lake. Arch. Hydrobiol. 148, 533-548.

Rodrigo, M.A., Miracle, M.R. \& Vicente, E. (2001). The meromictic Lake La Cruz (Central Spain). Patterns of stratification. Aquat. Sci. 63, 406-416.

Romero-Viana, L., Julia, R., Camacho, A., Vicente, E. \& Miracle, M.R. (2008). Climate signal in varve thickness: Lake La Cruz (Spain), a case study. J. Paleolimnol. 40, 703-714.

Romero-Viana, L., Keely, B.J., Camacho, A., Vicente, E. \& Miracle, M.R. (2010). Primary production in Lake La Cruz (Spain) over the last four 
centuries: reconstruction based on sedimentary signal of photosynthetic pigments. J. Paleolimnol. 43, 771-786.

Sadler, P.M. (1981). Sediment accumulation rates and the completeness of stratigraphic sections. J. Geol. 89, 569-584.

Saito, M.A., Sigman, D.M. \& Morel, F.M.M. (2003). The bioinorganic chemistry of the ancient ocean: the co-evolution of cyanobacterial metal requirements and biogeochemical cycles at the Archean-Proterozoic boundary? Inorg. Chim. Acta 356, 308-318.

Schönheit, P., Moll, J. \& Thauer, R.K. (1979). Nickel, cobalt, and molybdenum requirement for growth of Methanobacterium thermoautotrophicum. Archives of Microbiology 123, 105-107.

Siever, R. (1992). The silica cycle in the Precambrian. Geochim. Cosmochim. Acta 56, 3265-3272.

Smith, L.L.J.R. (1940). A limnological investigation of a permanently stratified lake in the Huron Mountain region of northern Michigan. Pap. Michigan Acad. Sci. Arts Lett. 26, 3-9.

Steenbergen, C.L.M. \& Korthals, H.J. (1982). Distribution of phototropic microorganisms in the Anaerobic and Microaerophilic Strata of Lake Vechten (the Netherlands) - pigment analysis and role in primary production. Limnol. Oceanogr. 27, 883-895.

Steenbergen, C.L.M. \& Verdouw, H. (1982). Lake Vechten - aspects of its morphometry, climate, hydrology and physicochemical characteristics. Hydrobiologia 95, 11-23.

Strauss, H., Chmiel, H., Christ, A., Fugmann, A., Hanselmann, K., Kappler, A., Königer, P., Lutter, A., Siedenberg, K. \& Teichert, B.M. (2015). Multiple sulphur and oxygen isotopes reveal microbial sulphur cycling in spring waters in the Lower Engadin, Switzerland. Isot. Environ. Health Stud., 1-19.
Suits, N.S. \& Wilkin, R.T. (1998). Pyrite formation in the water column and sediments of a meromictic lake. Geology 26, 1099-1102.

Sun, S., Konhauser, K.O., Kappler, A. \& Li, Y.-L. (2015). Primary hematite in Neoarchean to Paleoproterozoic oceans. Geol. Soc. Am. Bull. 127, 850-861.

Swain, E.B. (1984). The paucity of blue-green algae in meromictic Brownie Lake: iron-limitation or heavy-metal toxicity. [Ph.D. thesis]. University of Minnesota, Minneapolis, $362 \mathrm{p}$.

Vangemerden, H. (1984). The sulfide affinity of phototrophic bacteria in relation to the location of elemental sulfur. Arch. Microbiol. 139, 289-294.

Verdouw, H. \& Dekkers, E.M.J. (1980). Iron and manganese in Lake Vechten (the Netherlands) - dynamics and role in the cycle of reducing power. Arch. Hydrobiol. 89, 509-532.

Walker, J.C.G. (1984). Suboxic diagenesis in banded iron formations. Nature 309, 340-342.

Widdel, F., Schnell, S., Heising, S., Ehrenreich, A., Assmus, B. \& Schink, B. (1993). Ferrous iron oxidation by anoxygenic phototrophic bacteria. Nature 362, 834-836.

Woese, C.R. (1987). Bacterial evolution. Microbiol. Rev. 51, 221-271.

Wu, W., Swanner, E.D., Hao, L., Zeitvogel, F., Obst, M., Pan, Y. \& Kappler, A. (2014). Characterization of the physiology and cell-mineral interactions of the marine anoxygenic phototrophic $\mathrm{Fe}(\mathrm{II})$ oxidizer Rhodovulum iodosum-implications for Precambrian Fe(II) oxidation. FEMS Microbiol. Ecol. 88, 503-515.

Zegeye, A., Ruby, C. \& Jorand, F. (2007). Kinetic and thermodynamic analysis during dissimilatory gamma-FeOOH reduction: formation of green rust 1 and magnetite. Geomicrobiol. J. 24, 51-64.

Zegeye, A. et al. (2012). Green rust formation controls nutrient availability in a ferruginous water column. Geology 40,599-602. 